\title{
The Fine Structure of the Skin of Poeciliid Fish, Black Molly
}

\author{
Kouichi YoshizaKI* and Tamotsu TAMUra* \\ (Received May 4, 1978)
}

\begin{abstract}
The presence of numerous cytoplasmic filaments and desmosomes represent a cytoplasmic characteristic of the epidermal cells. There are many microvilli on the free surface of every superficial epidermal cell. The dermis is composed of a collagenous fiber bundle and loose connective tissue. The cellular components of the dermis consist of fibroblasts, capillaries, bundles of nerve fibers, and melanophores. The melanophores are approximately $50 \mu \mathrm{m}$ in diameter, and fall into the category of the so-called micromelanophore.
\end{abstract}

It is said that the skin structure of fish is different from that of terrestrial vertebrate, since fish inhabit a different environment. Therefore, it is interesting to examine the skin structure of fish. Accordingly, several reports have been published on the skin structure, especially the whole skin, ${ }^{1-41}$ epidermis, $^{5-12)}$ or melanophore. ${ }^{13-18)}$ It seems useful to clarify the ultrastructure of the melanophore in the normal skin in order to study the development of melanoma. The black molly was selected for the present observation of the skin structure, since skin melanoma were known to develop in the hybrid between this species and the guppy. ${ }^{19,201}$ This paper is a presentation of the electron microscopic study on the skin structure of the black molly, with special reference to the melanophore.

\section{Materials and Methods}

We used black molly (Poecilia sphenops) that were brought from a commercial supplier. The species is one of the most popular tropical fishes belonging to the family Poeciliidae. The fish was cut in small pieces, and fixed in cold, $2.5 \%$ glutaraldehyde containing MLLONIG's phosphate buffer solution, and post-fixed in $2 \%$ osmium tetroxide containing MILloNig's phosphate buffer solution. After dehydrating the pieces by passing them through graded ethanol, they were embedded in Epon 812 . Thin sections were made by Sorval Porter-Blum MT-I ultramicrotome. The sections were double stained with a $2 \%$ aqueous solution of uranyl acetate and lead (Pb) staining solution, and examined with a JEM-T7S electron microscope. We also made semi-thin sections from the blocks embedded in epon for light microscopic observations. These sections were stained with Giemsa solution.

\section{Results and Discussion}

\section{General structure (Fig. 1)}

The epidermis of the black molly was $50-70 \mu \mathrm{m}$ in thickness, and consisted of 7-10 layers of epidermal cells, which rested on a basement membrane. The epidermal cell of the fin region was flat in shape. That of the head region was ovoid or polygonal.

The dermis could be divided morphologically into an inner and an outer part. The outer part was composed mostly of a collagenous fiber bundle measuring approximately $20 \mu \mathrm{m}$ in thickness. The inner part was composed of loose connective tissue, and some obvious cellular components were fibroblasts, capillaries, bundles of nerve fibers, and melanophores.

Melanophores were observed mostly forming one or more layers in the collagenous fiber bundle, though sometimes they appeared just beneath the basement membrane or in the inner part of the dermis.

\section{Epidermis}

For descriptive purposes the epidermis could be distinguished morphologically into three cell layers: superficial, intermediate, and basal. The superficial cell layer was a single row of cells at the outer surface of the epidermis (Fig. 2). The basal cell layer was a single row of ovoid cells adjacent to the outer surface of the basement membrane (Fig. 3). The intermediate cell layer was several rows of epidermal cells between the superficial

* Fisheries Laboratory, Faculty of Agriculture, Nagoya University, Nagoya 464 (吉崎幸一・田村 保：名古 屋大学農学部水産学教室). 
cell layer and the basal one. Proceeding from the superficial cells to the basal the following progressive differences were detected: the cells and their nuclei became more ovoid, the intercellular space became wider, and the complexity and density of interdigitation increased in the epidermal cells of deeper layers.

The epidermal cells in all cell layers were typified by the attachment of desmosomes and interdigitations with adjacent cells. It is postulated that these structures are involved in maintaining the structure of the epidermis against environmental stresses. The cytoplasm of the epidermal cell in all cell layers was divided into two morphological zones: perinuclear and peripheral, as shown in Figs. 2 and 3. The perinuclear zone contained most of the cellular organellas, such as Golgi apparatus, mitochondria, rough-surfaced and smooth-surfaced endoplasmic reticula, and free ribosome. The peripheral zone contained numerous cytoplasmic filaments measuring approximately $80 \AA$ in diameter and free ribosomes. It can be considered that these filaments participate in maintaining the cytoarchitecture of the epidermal cell against environmental stresses, as HENRIKson and MATOLTSY $^{31}$ already discussed in other fishes. The free surface of the superficial cell possessed many microvilli measuring approximately $0.5 \mu \mathrm{m}$ in height and approximately $0.4 \mu \mathrm{m}$ in width. The surface of these microvilli was covered with an electron dense mucous-like material measuring approximately $0.05 \mu \mathrm{m}$ in thickness (Fig. 2). It can be considered that these microvilli aid in holding the mucous-like material, as HAwKEs ${ }^{2}$ already stated in salmon.

The present observation reveals that the characteristics of the epidermis of the black molly is essentially similar to that of other species of fishes. ${ }^{1-121}$

\section{Dermis}

The basement membrane was approximately $0.2 \mu \mathrm{m}$ in thickness, and located between the inner membrane of the basal epidermal cells and the collagenous fiber bundle of the dermis (Fig. 3). This membrane was separated from the overlying basal cell by a space approximately $0.08 \mu \mathrm{m}$ in width. This space was relatively electron lucent, and its basal lamella was electron dense.

The outer part of dermis consisted mainly of collagenous fibers forming lamellae of approximately $0.2 \mu \mathrm{m}$ in thickness. Each lemalla ran in a plane parallel to the body surface. The individual collagenous fibers of each lamella were oriented in parallel. The longitudinal axes of the collagenous fibers of each lamella were perpendicular to the axes of the lamellae immediately above and below, as was seen in the upper part of Fig. 4. It is assumed that the collagenous fiber bundle maintains the structure of the epidermis and the dermis. The inner part of dermis consisted mainly of amorphous intercellular matrix. The cellular components observed in this matrix were as follows: fibroblasts, capillaries, bundles of nerve fibers, and melanophores. The fibroblasts lay scattered in the matrix, and sometimes occurred between the collagenous lamellae, and they were spindle-shaped and had long, fine cytoplasmic processes. The capillaries lay scattered in the matrix, and its lumen was lined by a single layer of endothelial cells. There were numerous pinocytotic vesicles all around the cell membrane.

\section{Melanophore}

The melanophore was typified by numerous, branching, cytoplasmic processes, and by many melanosomes. Although all the melanophores and their nuclei had approximately the same size, the quantity of melanosomes differed from cell to cell. The melanophores including few melanosomes tended to occur deeper in the dermis than those including abundant melanosomes. The melanophores including fewer melanosomes were abundant in the mitochondria, smooth-surfaced endoplasmic reticulum, and free ribosome (Figs. 5 and 6). The numerous pinocytotic vesicles all around the cell membrane were ovoid in shape, and measured $0.1 \mu \mathrm{m}$ in diameter. Their nuclei were very irregular in shape, and the chromatin tended to aggregate along the nuclear membrane. Furthermore, the nucleoli were frequently obvious. In the melanophores containing abundant melanosomes (Figs. 7 and 8), fewer organelles were observed, because the melanosomes occupied most of the cytoplasm. Their nuclei were somewhat irregular in shape. They had sometimes a deep indentation, and their nucleoli could not be observed.

Two sizes of melanophores are generally recognized in the fish skin: macromelanophores and micromelanophores. ${ }^{18,21}$ Macromelanophores are responsible for a large black spotted condition, and they are approximately $300 \mu \mathrm{m}$ in diameter. Micromelanophores are responsible for a small black spotted condition or a black stippled pattern, and they are approximately 100 
$\mu \mathrm{m}$ in diameter. Although there were differences in the quantity of melanosomes and the shape of their nuclei, the other ultrastructural features were about the same among the melanophores investigated. Therefore, it is reasonable to conclude that the black molly has only one type of melanophores. The melanophores of the black molly were approximately $50 \mu \mathrm{m}$ in diameter and did not exceed $100 \mu \mathrm{m}$, and their nuclei were $10-20 \mu \mathrm{m}$ in diameter. Accordingly, it is conceivable that the melanophore of the black molly is a so-called 'micromelanophore' and not 'macromelanophore.' The intensely dark coloring of the black molly is due to an excessive number of micromelanophores, as GHADIALLY and GORDON $^{191}$ and STOLK ${ }^{201}$ already stated.

\section{Acknowledgement}

We are grateful to Associate Professor M. Oguri, Faculty of Agriculture, Nagoya University, for helpful suggestions and a critical reading of the manuscript.

\section{References}

1) J. E. Harris and S. Hunt: Cell Tiss. Res., 163, 553-565 (1975).

2) J.W. HaWkes: Cell Tiss. Res., 149, 147-158 (1974).

3) R.C. Henrikson and A.G. Matoltsy: J. Ultrastruc. Res., 21, 194-212 (1968).
4) S. M. KitZAN and R. Sweeny: Canad. J. Zool., 46, 767-772 (1968).

5) A. K. Mittal and J. S. Datra Munshi: $J$. Morph., 130, 3-10 (1970).

6) M. Schliwa: J. Ultrastruc. Res., 52, 377-386 (1975).

7) J. YAMADA: Amnot. Zool. Jap., 41, 1-8 (1968).

8) G. A. Brown and S. D. Wellings: Z. Zellforsch., 103, 149-169 (1970).

9) R. FuנI: Annot. Zool. Jap., 41, 95-106 (1968).

10) L. C. U. Jungueira, A. M. S. Toledo and K. R. PORTER: Arch. Histol. Jap., 32, 1-15 (1970).

11) W. J. R. LANZING and R. G. Wright: Cell Tiss. Res., 154, 251-264 (1974).

12) R. J. Roberts, H. Joung, and J. A. Milne: $I$. Fish Biol., 4, 87-98 (1972).

13) R. Fusu: Annot. Zool. Jap., 39, 185-192 (1966).

14) L. Green: Proc. N. A. S., 1179-1186 (1968).

15) J. W. Hawkes: Cell Tiss. Res., 149, 159-172 (1974).

16) H. Imaki and W. Chavin: Cell Tiss. Res., 158, 363-375 (1975).

17) I. KameI-TAKeuch and T. Ka.jishima: Annot. Zool. Jap., 44, 23-31 (1971).

18) R. G. LUTFY: Cellule, 61, 357-365 (1961).

19) I. N. Ghadially and M. Gordon: Cancer Res., 17, 597-599 (1957).

20) A. Stolk: Proc. K. ned. Akad. Wet., 61, 499-514 (1958).

21) H. J. Sobel, E. Marquet, K. D. Kallman, W. E. Ribelin, G. Mrgaki, and G. J. Corley: in "Pathology of Fishes" (ed. by W. E. RIBELIN and G. Migakl) The University of Wisconsin Press, Madison, 1975, pp. 945-981. 


\section{Explanation of plate 1 and 2.}

Fig. 1. General skin structure of the black molly. Giemsa stain.

Fig. 2. Superficial cell of the epidermis.

Fig. 3. Basal cell of the epidermis.

Fig. 4. General structure of the dermis.

Fig. 5. Melanophore including relatively few melanosomes.

Fig. 6. Detail of Fig. 5.

Fig. 7. Melanophore including abundant melanosomes.

Fig. 8. Detail of Fig. 7.

$\mathrm{Bm}$ : basement membrane, $\mathrm{Co}$ : collagenous fiber bundle, $\mathrm{Cp}$ : capillary, $\mathrm{D}$ : dermis, Ep: epidermis, M : muscle, Me: melanophore. 


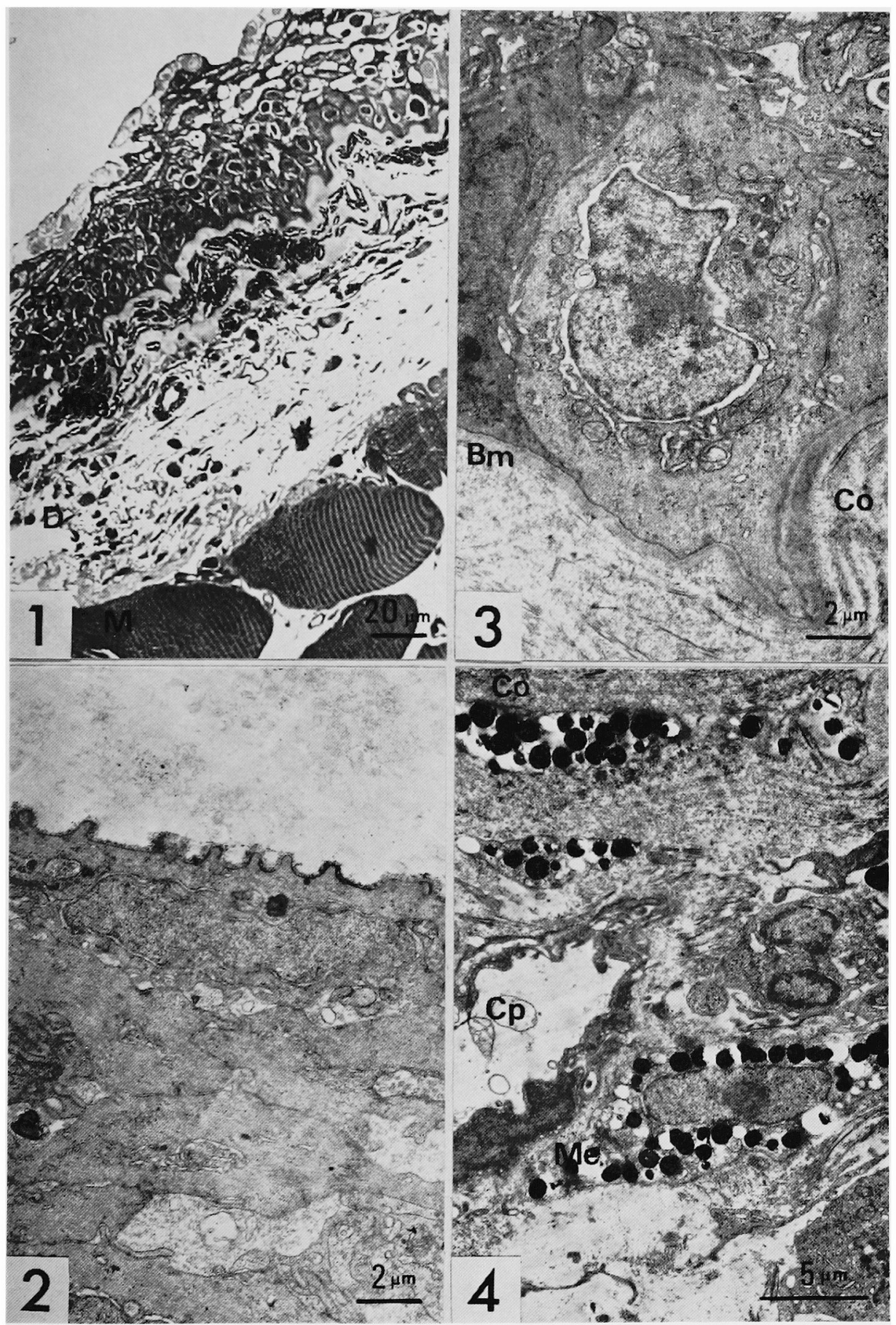




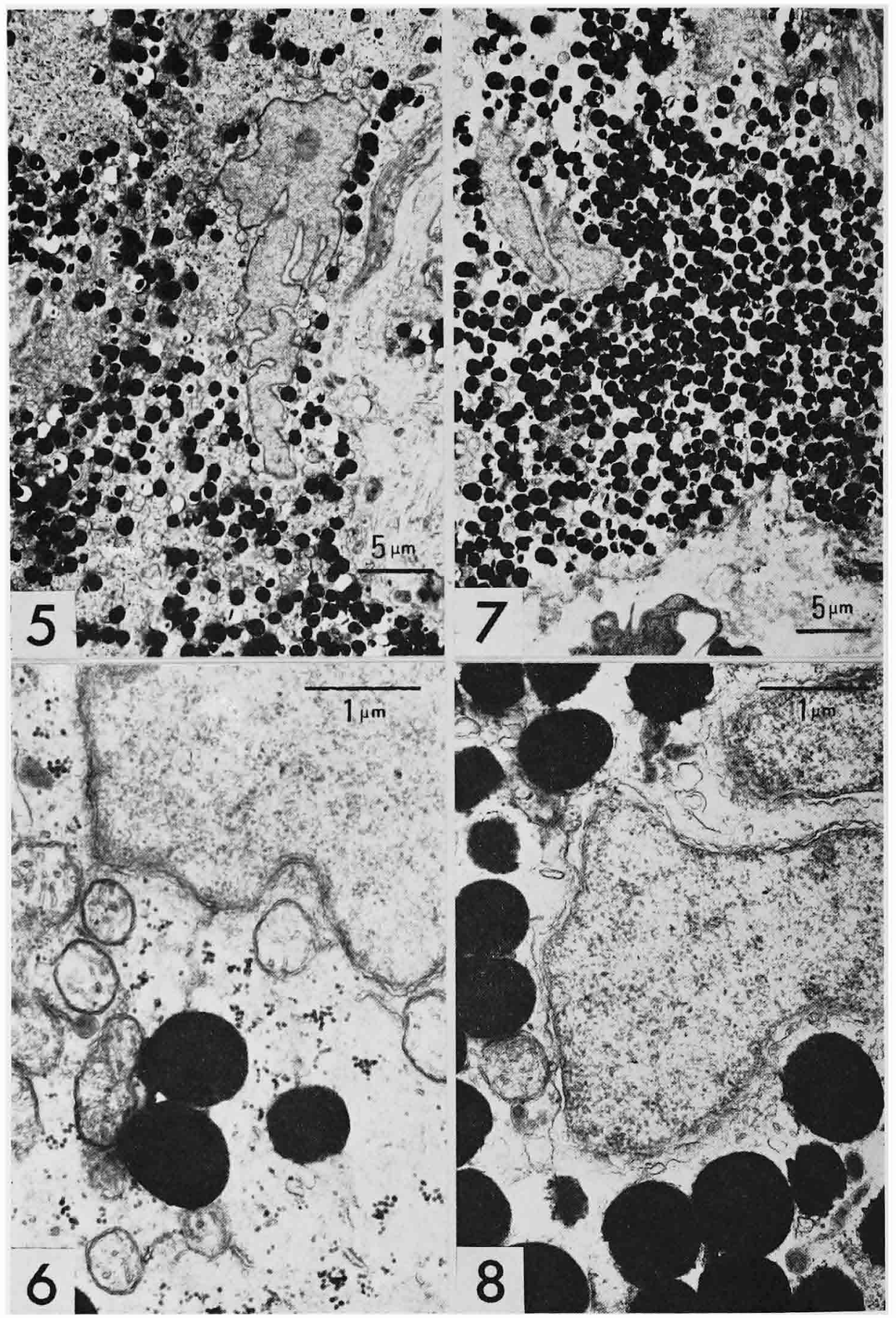

